\title{
Third-party enterprises' perceptions of green logistics in China
}

\author{
Hyunggeun Kim*, Jungseok Choi* ${ }^{* *}$
}

\begin{abstract}
This article represents an empirical examination of green logistics awareness of employees at third-party enterprises in China. The data used for this study was collected using a survey related to green logistics awareness. Participants were employees of Chinese enterprises, including five logistics companies. Although there was a general low level of green logistics awareness, results showed a diverse awareness of the topic contingent upon green logistics knowledge. More specifically, with the exception of those who demonstrated a high degree of green logistics knowledge, green logistics awareness level and other dimensions were low. In addition, educational background demonstrated an influence on green logistics awareness. The findings from this study have real-world implications for the development of state logistics environmental protection policy.
\end{abstract}

Keywords : China, logistics enterprise, green logistics, environmental perception

JEL Classification : M19, M20, F14

* First author, Assistant Professor, Division of Chinese Studies (Dept. of Chinese Economics), Silla University, 140 Baegyang-daero(Blvd) 700 beon-gil(Rd), Sasang-gu, Busan, Korea, e-mail:kimhg@silla.ac.kr

${ }^{* *}$ Corresponding author, Assistant Professor, Division of Chinese Studies (Dept. of Chinese Economics), Hanyang University, 222 Wangsimni-ro, Seongdong-gu, Seoul 133-791, Korea, e-mail:ayuwa@daum.net 


\section{Introduction}

Logistics plays a significant auxiliary role in the development of an economy. However, when the logistics industry makes significant contributions to modern economic development, it can generate negative effects, such as environmental pollution and a waste of resource. Striking a balance between economic contribution and environmental protection is an urgent issue for governments and environmental institutes worldwide. To resolve this dilemma, green logistics has been developed. Generally, enterprise officials implement green logistics. Its successful implementation, however, depends on the detailed operations of the enterprise and employees' values concerning green logistics. Therefore, research related to green logistics awareness and the behavior tendencies of those who implement green logistics will (a) provide an insight regarding the practice of green logistics, (b) standardize enterprise green logistics behavior, and (c) promote enterprise green logistics policy-making.

Negative ecological effects (e.g., global warming) resulting from some business practices have spurred the motivation to develop methods for achieving eco-friendly and sustainable development alternatives. Sustainable development meets current business needs, but does not reduce the quality and quantity of resources. In this way, future generations are able to meet their needs as well (WCED 1987). Generally, sustainable development is designed to simultaneously protect the environment and address relevant socioeconomic issues. Around the world, companies have felt the pressure to implement environmental protection measures while maintaining the value creation system for which the enterprise is designed.

This increasing pressure, coupled with the rising prices of raw materials and energy, new environmental legislation, and influence of the dominant actors in the value chain, has led to a growing environmental awareness among consumers in many countries (Carter \& Ellram 1998, Ferguson \& Browne 2001, Fleischmann et al. 1997, Kumar \& Malegeant 2006, Seuring \& Müller 2008, Stock 2001, Voigt \& Thiell 2004). Indeed, solutions have been proposed to address these issues. These solutions have taken several forms, including improving the lower end of the raw materials value chain, reducing consumer and industrial pollution, and reducing domestic residuals after use.

Logistics activities are cross-functional and cross-organizational. The successful control and implementation of these processes are referred to as "logistics management" (Wu \& Dunn 1995). It is widely acknowledged that logistics have a simultaneous positive effect on service manufacturing processes and unavoidable damage on the environment. For example, although transportation is a critical logistics operation, carbon dioxide emissions of vehicles, aircraft, and ships (often considered one of the primary contributors 
to global warming) threatens the health of the world environment (Berntsen \& Fuglestvedt 2008). As a result, the implementation of green logistics has become a key component in achieving sustainable management.

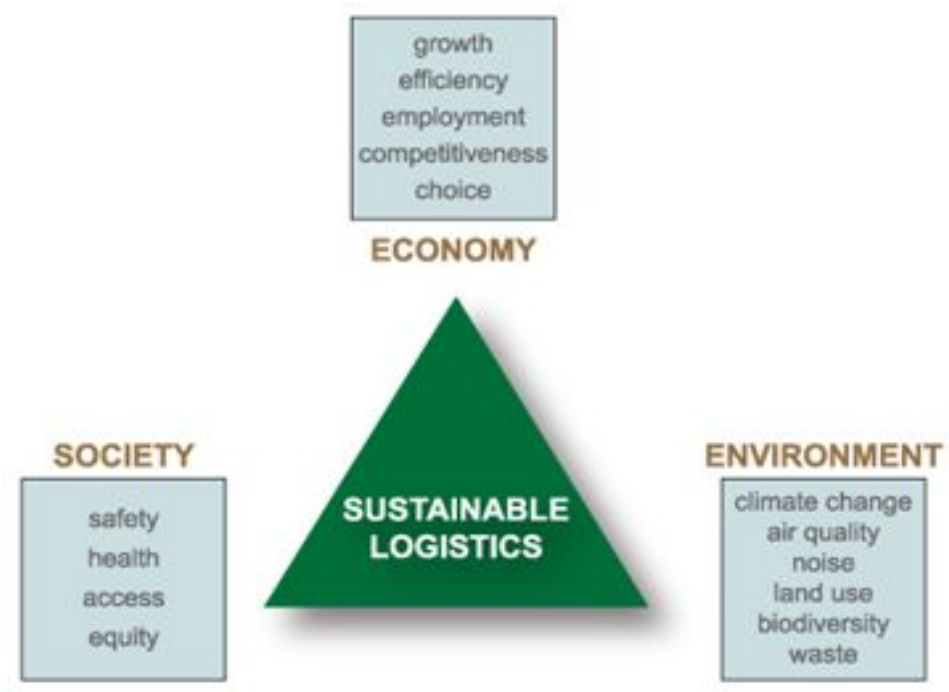

Figure 1.

Concept of green logistics 1 )

\section{Review of literature on Theoretical research of green logistics}

Extant logistics research has focused primarily on the relationship between supply chain management and logistics performance evaluation. Comparatively, there has been very little research related to green logistics. The primary goal of green logistics is to limit environmental damage from logistics practices while making full use of resources. Western scholars began to study green logistics in the 1960s, but experimental testing related to green logistics theory was scarce until the 1990s. In 1995, Murphy et al. brought green logistics to the forefront of many research agendas. Later, Carter and Jennings (2002) found that social logistics values and the faith of a green logistics manager significantly influenced the performance of logistics' social duties.

As evidenced by these examples, it is clear that green logistics has been deemed

1) http://www.greenlogistics.org/ 
important in the West. However, it is new to Chinese industrial and academic circles. Most research by Chinese scholars has been qualitative so far. Very little quantitative empirical work in this area has been conducted. Wang Bei and Sun Linyan established multi-index reserve logistics operating decision-making evaluation mode with internal relation and applied network analysis method (ANP) to verify the rationality and practical applicability. $\mathrm{Yu}$ Chengxue evaluated green logistics management in three capacities: green logistics influence factors, green environmental behaviors, and green performance. From these evaluations, Chengxue constructed a system for indexing types of green logistics management. From these empirical efforts, it is clear to see that scholars have begun to actively explore environmental awareness and environmental logistics. However, those outside academia have integrated the two areas of research. Environmental awareness indicates an awareness of green logistics. Green logistics awareness, in turn, refers to an overall degree of understanding related to logistics environmental problems and the efforts directed at resolving these problems. This article analyzes the constitutive dimension of green logistics awareness by measuring the green logistics awareness of relevant workers and examining the influence of demographic variables on green logistics awareness.

Some have defined green logistics as an activity that promotes sustainable development by establishing a circulatory system of resources that reduces waste in an environment-friendly manner.They argued that green logistics preserves resources, promotes recycling, uses eco-friendly substitutes, and save raw materials (Oh \& Lee 2001, Jeong \& Lee 2005). Similarly, Kim (2001) said that green logistics refers to all logistics management activities related to a replacement plan for production methods, consumption methods, and logistics systems that may reduce the weight of products and packaging materials. In addition, the re-creation of value added by way of recovering, sorting, transporting, and recycling waste is indicative of green logistics (see also Rao \& Holt 2005). Wang (2004) defined green logistics as a method to control the inherent environmental harm associated with traditional logistics activities. Park \& Lee (2006) defined it as an activity that can fundamentally eliminate or minimize environmentally hazardous elements in production processes. These processes range from the search of raw materials to delivery to the consumer.

Srivastara (2007) described green logistics as an integrative consideration of the environmental impact of logistics management (including product design, materials selection, manufacturing, transfer of finished products to consumers, and end-of-life management after use). Lee (2010) defined it as a logistics system designed to control negative impacts on the global environment caused by both forward and reverse logistics. 


\section{Table 1.}

Definitions of green logistics

\begin{tabular}{|c|c|}
\hline Researcher & Definition \\
\hline $\begin{array}{l}\text { Wang Bei } \\
\& \text { Sun Linyan }\end{array}$ & $\begin{array}{l}\text { - multi-index reserve logistics operating decision-making evaluation } \\
\text { mode with internal relation } \\
\text { - applied network analysis method (ANP) to verify the rationality and } \\
\text { practical applicability }\end{array}$ \\
\hline Yu Chengxue & - enterprise green logistics management in three capacities \\
\hline Oh \& Lee (2001) & - saves resources and promotes recycling of goods \\
\hline $\operatorname{Kim}(2001)$ & $\begin{array}{l}\text { - involves all logistics management activities related to the } \\
\text { implementation of a replacement plan for production methods, } \\
\text { consumption methods, and logistics systems }\end{array}$ \\
\hline Wang (2004) & $\begin{array}{l}\text { - imperative for controlling the environmental harm created by logistics } \\
\text { - purifies logistics environment and ensures that logistics resources are } \\
\text { sufficiently used }\end{array}$ \\
\hline Jeong \& Lee (2005) & $\begin{array}{l}\text { - promotes sustainable development by contributing to the preservation of } \\
\text { resources, promotion of recycling of goods, and use of eco-friendly } \\
\text { substitutes }\end{array}$ \\
\hline Rao \& Holt (2005) & $\begin{array}{l}\text { - describes the effect of both forward and backward logistics activities on } \\
\text { the environment }\end{array}$ \\
\hline Park \& Lee (2006) & $\begin{array}{l}\text { - fundamentally eliminates or minimizes environmentally hazardous } \\
\text { elements in all logistics processes }\end{array}$ \\
\hline Srivastara (2007) & $\begin{array}{l}\text { - integrative consideration of the environmental impact of logistics } \\
\text { management at all stages }\end{array}$ \\
\hline Lee $(2010)$ & $\begin{array}{l}\text { - designed to control the negative impact of forward and backward } \\
\text { logistics on the global environment }\end{array}$ \\
\hline
\end{tabular}

Source : Author's research.

\section{The current status of green logistics in China}

Since China's inception, its economic development has experienced substantial difficulty. It was not until 1978 that the Chinese population became optimistic about the Chinese economy. The Chinese government reformed the economy, opening a system that had historically been closed from the rest of the world. This benefitted the Chinese gross 
domestic product (GDP) greatly. With the rapid growth of the Chinese GDP, great number of people enjoyed the economic benefits that came with it. Many new industries arrived, and with them came further economic development. Simultaneously, logistics industries became an integral part of these new industries. Owing to the increased demand for logistics professionals, many universities began offering courses on this subject. Most students of logistics have been able to find a job. Despite the rapid development of logistics in China, some major problems emerged. First, logistics tend to be an expensive component of conducting business. Second, the concept of logistics is to be refined. Finally, as mentioned above, logistics is often harmful to the environment. I will discuss each of these issues below.

First, the most challenging problem associated with Chinese logistics is its high cost. According to Bolton (2003), "Morgan Stanley estimated that in 2001, logistics spending in China amounted to one-fifth of the nation's GDP and twice the proportion spent on logistics in the United States." Given this, Chinese logistics add less value to services and cannot adapt to new international trends. The article "Several problems in the logistics sector in China" (2011) explained that new trends in distribution are polytypic, high-frequency, and based on a model that utilizes a small number of transport methods. However, the limited value added to Chinese services by Chinese logistics does not meet the same standards as that of the international logistics market. A second problem associated with the high cost of logistics is caused by regional protectionism. In China, most of the logistics systems are independent and lack interdependence or cooperation. According to Hong (2007), "local authorities are obsessed by local economic growth, and build some barriers to keep out products from other regions, which have hindered the development of the logistics sector." This competition can waste Chinese resources. For instance, "70 percent of China's commercial enterprises and 53 percent of industry enterprises own their own vehicle fleet, and 80 percent and 59 percent, respectively, own warehouse facilities" (Bolton, 2003). The competition between logistics systems is a detriment to the overall economic well-being in China. Thirdly, the organization and management functions critical to the performance of logistics contributes to its high cost. With respect to the organization and management of logistics, China trails the USA and Japan to a great degree. As described by "Several problems in the logistics sector in China" (2011) administrative expenses are very high in China (2.5\% of GDP, compared to $0.4 \%$ in the U.S.). This is primarily owing to the limitation in economic systems, domestic services, and monopolies. A fair logistics has yet to be built in China, and thus, there is no mechanism for open and free logistical functions. The fourth cost-related problem with logistics is the high warehousing costs. This problem mostly results from high inventory levels in China. Higher warehousing costs imply a greater amount of capital equipment, 
low-incomes, and reduced competitiveness. In short, many practical cost-related problems with logistics were masked by its rapid development.

The second problem associated with logistics in China relates to its need for improvement. Most pressingly, the concept of logistics management in many enterprises is regressive and needs to be improved. The article "China's retail logistics management problems and countermeasures" (2011) explained that although many enterprises set up a department of logistics management, these departments are often inefficient and are not equipped to handle information or cash flow properly. Additionally, according to "China's retail logistics management problems and countermeasures" (2011), many logistics companies have built their networks of distribution gradually strengthen them to seize market opportunities. The relatively low extent to which logistics companies of share information is also a problem. Many companies have made improvements in logistics information technology. For example, Hong (2007) found that "about 43 percent need logistics system designers and logistics information managers, which implies that some companies plan to involve in these activities due to increasing needs for these "high-level" logistics services in the Chinese market." However, entrepreneurs have yet to satisfactorily use logistics management. Traditional business logistics and manual distribution centers are still widely used, which not only inefficient but also highly prone to errors. Moreover, failure to appreciate the role of logistics information systems will restrict the efficiency of logistics operations and the quality of a firm's service may suffer as a result.

Finally, there exist problems associated with the development of green logistics. Environmental issues are important for nearly every field in social economy. This includes the logistics industry. Green logistics refers to the presentation of the environment by reducing pollution and resource consumption while achieving business objectives. Unfortunately, in China, the practice of green logistics is still limited. First of all, green logistics is poorly understood by many people in China because it is a relatively new concept (Green logistics development in China Problems and Solutions, 2010). In China, green logistics is just thought to be a theory rather than a tangible practice. In addition, green logistics systems are incomplete and relevant policy has yet to be established in China. According to "Green logistics development in China Problems and Solutions" (2010), green logistics can serve as an important factor in developing an improved economic and living standards. As such, the development of green logistics is a relevant issue for both government officials and consumers alike. Although green logistics, as a mechanism for the market, is able to self-regulate, it also needs governmental oversight and policy to support it because it has recently emerged in China. However, China has not established a department for planning or managing green logistics. Responsibility for the management of green logistics is unclear, and resources are wasted as a result. A lack of 
equipment and technological infrastructure also plagues the development of green logistics. There currently exists a wide gap between China's green technology and the extent to which developed countries have automated their logistics systems. Vicious competition within the logistics industry not only pollutes the environment, but also limits the development of green logistics. In addition, there are very few highly educated individuals that can work to implement green logistics. The article "Green logistics development in China Problems and Solutions" (2011) explained that competition between modern logistics enterprises in the competition between logistics talents. The development and implementation of green logistics has been delayed in China (relative to other developed countries), so the green logistics training programs similarly lag behind those of other countries. To remedy this, many colleges have established academic programs to train individuals to implement green logistics. Unfortunately, most of the professionals lack practical experience. As a result, the preliminary development of green logistics in China has suffered from a number of workers who are not only ill-prepared but also lack a formal education in professional logistics. In sum, the problems associated with improving green logistics cannot be ignored if overall logistics in China are to improve.

All in all, there are several problems related to the process of developing logistics in China. The high cost of logistics, the shortcomings of current logistics management practices, and the drawbacks of developing green logistics are all important problems that must be faced. Doing so does not imply that the development of logistics in China is impossible. In reality, the Chinese logistics development is moving in the right direction. Hong (2007) said that "in light of the increasing interest in both third-part logistics (3PL) providers and China as an emerging player in the world economy, an understanding and assessment of China's logistics service providers is appropriate and timely." A consideration of these problems will only improve logistics.

\section{Research Design}

The data for this study were collected from a survey that was based on documentation and materials related to green logistics, that is Dunlap's (2000) NEP table, and Yu chengxue's enterprise green logistics management evaluation table. For the survey consists of two parts: Part I relates to green logistics awareness and consists of several 5-point Likert-type items ranging from extremely dissatisfied to extremely satisfied. Part II relates to the status quo of green logistics cognition. 


\subsection{Data source}

Questionnaires were distributed to the employees of more than ten Chinese enterprises in 2011. The majority of these were third-party logistics companies with great representativeness. These include $\bigcirc \bigcirc$ city $\bigcirc \bigcirc \bigcirc$ Logistics Company, $\bigcirc \bigcirc$ Express, and OLogistics.

Choosing employees of the third-party companies as respondents allows for an examination of logistics professionals. As a result, the current study has direct applicability for the development of environmental protection policy related to state logistics. A total of 150 surveys were handed out, and 137 surveys (94.8\%) were returned. Demographic information for respondents is shown in Table 2.

Table 2.

Sample demographics

\begin{tabular}{|c|c|c|c|}
\hline Division & Type & Number of people & Percentage \\
\hline \multirow{2}{*}{ Sex } & Male & 94 & 71.56 \\
\hline & Female & 38 & 28.45 \\
\hline \multirow{5}{*}{$\begin{array}{l}\text { Education } \\
\text { background }\end{array}$} & Primary school & 13 & 9.05 \\
\hline & Middle school & 16 & 12.07 \\
\hline & High school & 42 & 31.90 \\
\hline & Undergraduate & 60 & 46.12 \\
\hline & Master's degree & 1 & 0.86 \\
\hline \multirow{4}{*}{ Income } & Below 1,000 Yuan & 18 & 14.22 \\
\hline & 1,001 2,000 Yuan & 74 & 56.50 \\
\hline & 2,001 3,500 Yuan & 27 & 20.69 \\
\hline & More 3,500 Yuan & 13 & 8.62 \\
\hline \multirow{3}{*}{ Tenure } & Below 1 year & 28 & 21.56 \\
\hline & $1 \sim 5$ years & 88 & 66.81 \\
\hline & More 5 years & 16 & 11.64 \\
\hline \multirow{3}{*}{ Position } & Senior managers & 14 & 10.78 \\
\hline & Middle managers & 28 & 21.12 \\
\hline & Staff & 90 & 68.10 \\
\hline \multirow{2}{*}{$\begin{array}{c}\text { Family } \\
\text { background }\end{array}$} & City & 74 & 56.50 \\
\hline & Countryside & 58 & 43.53 \\
\hline \multirow{3}{*}{ Company Property } & State-owned enterprises & 17 & 13.36 \\
\hline & Private enterprises & 69 & 52.59 \\
\hline & Foreign enterprises & 46 & 34.05 \\
\hline
\end{tabular}

Source : Author's research. 


\subsection{Research progress}

Data were analyzed in two stages. First, descriptive statics were observed to evaluate the status quo of green logistics development. Second, a principal component factor analysis with varimax rotation was conducted to confirm the green logistics awareness dimension outlined above.

\section{Analysis on Empirical Method}

\subsection{Statistics and description}

The result of our survey revealed that $46.6 \%$ of respondents in the study considered the present practices for implementing green logistics implementation to be "ordinary," $37.9 \%$ interviewees of respondents it "bad," and 6\% "extremely bad." In contrast, 9.5\% of respondents determined it to be good. It is obvious that the respondents have had a generally negative evaluation of how logistics are currently implemented. More males than females evaluated the current green logistics practices as bad. Further, $47 \%$ of males and $35.5 \%$ of females responded that the development of green logistics is poor.

Although most respondents evaluated green logistics implementation negatively, they showed optimism with regard to the improvement of the logistics environment. For example, $16.4 \%$ of respondents predicted that scientific improvements may completely eliminate the negative influence of logistics on the environment, and $52.2 \%$ of respondents believed that technology can resolve the logistics-environment problem to a great extent. About $71.4 \%$ of females gave positive evaluations of how the logistics-environment relationship is developing, $3 \%$ higher than that of males.

With respect to where respondents obtained their logistics knowledge, 56.5\% obtain their knowledge online, 32.8\% from their working unit, $30.2 \%$ from journals and magazines, and $24.6 \%$ from professional education and promotional activities. Given this, it seems that one's network, besides journals and magazines, is the principal channel for learning about green logistics. According to the responses to questions related to the main driving factors for green logistics implementation, $45.5 \%$ of respondents claimed that the primary driver of green logistics development should be laws and regulations, $28 \%$ that a favorable economic and cultural environment can promote the development of green logistics, and $9.5 \%$ that environmental policy is the most important factor for the development of green logistics. With regard to impediments of green logistics development, 
$42.7 \%$ of people considered that the biggest obstacle for green logistics development is poor laws and systems, $38.4 \%$ of respondents said that a lag in adoption by enterprises and consumers is the biggest hindrance, $5.6 \%$ of respondents claimed that enterprise cooperation represents the largest impediment, and $4.7 \%$ responded that insufficient enterprise logistics experience and skills are the chief factors restraining green logistics development. Responses to this questionnaire suggest that the government legislation of green logistics is widely thought to be critical to its development.

\subsection{Factor analysis on constituent dimension of green logistics awareness}

Factor analysis is a statistical method used to identify subsets of concepts within a given series of observances according to the relation of variances. In this study, factor extraction was achieved using a principal component analysis with orthogonal rotation and variance maximization. According to Bartlett's value (2599.9216; $\mathrm{p}<.001)$ and KMO's value (0.828), the results of the factor analysis can be deemed valid. Results showed that the various measurement items used in the questionnaire can be divided into four factors. The accumulated variance contribution rate reached $76.1 \%$, indicating that the four factors explain over three-fourths of the variance in the questionnaire. With respect to reliability estimates, Cronbach's a of the overall questionnaire was 0.866 , indicating a relatively high degree of reliability among the items. Cronbach's a for from the four factors ranged from 0.625 to 0.970 .

The results of the factor analysis validated the design of the questionnaire. The four common factors proposed after dimension reduction were indicative of the detailed constituent dimension of green logistics awareness. Results are summarized in Table 3. Factor 1 explains $40.966 \%$ of overall variance in the questionnaire, the greatest proportion among the factors. Cronbach's a for this factor is very high (0.956), suggesting high intra-factor consistency. The factor contains six items related to green logistics awareness, and thus, it is appropriate to name the factor "green logistics attitude." Factor 2 also demonstrated a high factor loading (.709). These items were all related to green logistics knowledge, and as a result, this factor was named "green logistics knowledge." This factor explained $14.620 \%$ of the variance in green logistics awareness, showing that knowledge is an important contributor to logistics awareness. Factor 3 relates to the detailed behavior of the respondent regarding environmental protection and resource-saving. Thus, it is named "green logistics behavior." This factor explained $13.182 \%$ of the overall variance in green logistics awareness, and Cronbach's a for this factor was very good, at 0.970 . Factor 4 is called "green logistics desire." The factor primarily reflects the respondent's desire to 
implement logistics environmental protection and receive green logistics education and training. Further, $7.325 \%$ of the variance in green logistics awareness could be explained by this factor, whose Cronbach's a is 0.625 . Although this reliability estimate is lower than the overall reliability of the entire scale and the other factors, it is still acceptable.

\section{Table 3.}

Results of factor analysis.

\begin{tabular}{|c|c|c|c|c|c|c|c|}
\hline Factor & $\begin{array}{l}\text { Measured } \\
\text { variables }\end{array}$ & Load & Eigenvalue & $\begin{array}{c}\% \text { of } \\
\text { variance }\end{array}$ & $\begin{array}{l}\text { Cumulative } \\
\text { percentage }\end{array}$ & $\begin{array}{l}\text { Relative } \\
\text { importance }\end{array}$ & Cronbach's a \\
\hline \multirow{6}{*}{$\begin{array}{c}\text { Factor } \\
1\end{array}$} & $\begin{array}{c}\text { Green logistics } \\
\text { demand }\end{array}$ & 0.921 & \multirow{6}{*}{5.739} & \multirow{6}{*}{40.996} & \multirow{6}{*}{40.996} & \multirow{6}{*}{53.85} & \multirow{6}{*}{0.956} \\
\hline & $\begin{array}{c}\text { Logistics system } \\
\text { environmental } \\
\text { protection }\end{array}$ & 0.912 & & & & & \\
\hline & $\begin{array}{c}\text { Green logistics } \\
\text { legislation }\end{array}$ & 0.903 & & & & & \\
\hline & $\begin{array}{l}\text { Green logistics } \\
\text { responsibility }\end{array}$ & 0.891 & & & & & \\
\hline & $\begin{array}{c}\text { Reverse logistics } \\
\text { system }\end{array}$ & 0.870 & & & & & \\
\hline & $\begin{array}{l}\text { Green supply } \\
\text { chain } \\
\text { management }\end{array}$ & 0.811 & & & & & \\
\hline \multirow{4}{*}{$\begin{array}{c}\text { Factor } \\
2\end{array}$} & $\begin{array}{c}\text { Green logistics } \\
\text { level }\end{array}$ & 0.776 & \multirow{4}{*}{2.047} & \multirow{4}{*}{14.623} & \multirow{4}{*}{55.619} & \multirow{4}{*}{19.21} & \multirow{4}{*}{0.709} \\
\hline & $\begin{array}{c}\text { Green logistics } \\
\text { concept }\end{array}$ & 0.700 & & & & & \\
\hline & $\begin{array}{l}\text { Logistics } \\
\text { environment } \\
\text { damage }\end{array}$ & 0.687 & & & & & \\
\hline & $\begin{array}{c}\text { Green logistics } \\
\text { target }\end{array}$ & 0.678 & & & & & \\
\hline
\end{tabular}




\begin{tabular}{|c|c|c|c|c|c|c|c|}
\hline Factor & $\begin{array}{l}\text { Measured } \\
\text { variables }\end{array}$ & Load & Eigenvalue & $\begin{array}{c}\% \text { of } \\
\text { variance }\end{array}$ & $\begin{array}{l}\text { Cumulative } \\
\text { percentage }\end{array}$ & $\begin{array}{l}\text { Relative } \\
\text { importance }\end{array}$ & Cronbach's a \\
\hline \multirow{2}{*}{$\begin{array}{c}\text { Factor } \\
3\end{array}$} & $\begin{array}{c}\text { Use of } \\
\text { environment-frie } \\
\text { ndly materials }\end{array}$ & 0.971 & \multirow[b]{2}{*}{1.845} & \multirow[b]{2}{*}{13.182} & \multirow[b]{2}{*}{68.801} & \multirow[b]{2}{*}{17.34} & \multirow[b]{2}{*}{0.970} \\
\hline & $\begin{array}{l}\text { Logistics and } \\
\text { energy } \\
\text { consumption } \\
\text { savings }\end{array}$ & 0.963 & & & & & \\
\hline \multirow{2}{*}{$\begin{array}{c}\text { Factor } \\
4\end{array}$} & $\begin{array}{l}\text { Logistics } \\
\text { environment } \\
\text { willingness to } \\
\text { participate }\end{array}$ & 0.794 & \multirow[t]{2}{*}{1.206} & \multirow[t]{2}{*}{17.325} & \multirow[t]{2}{*}{76.126} & \multirow[t]{2}{*}{19.60} & \multirow[t]{2}{*}{0.625} \\
\hline & $\begin{array}{c}\text { Desire to receive } \\
\text { green logistics } \\
\text { education }\end{array}$ & 0.758 & & & & & \\
\hline
\end{tabular}

Source: Author's research

\subsection{Level evaluation of green logistics awareness}

The level of green logistics awareness and the scores of various associated factors formed the basis of a follow-up regression analysis. Authors first applied a regression model to calculate the score coefficient matrix $A(14 \times 4)$ of various common factors. Then matrix multiplication theory was applied to calculate the score matrix $F(232 \times 4)=X(232$ $\times 14) \times A(14 \times 4)$ of various factors. Finally, they used the factor score and relative importance matrix $B(4 \times 1)$ to calculate green logistics awareness (GLA). The level of green logistics awareness and average score of various dimensions are shown in Table 4.

Table 4.

Enterprise green logistics awareness level and factor point.

\begin{tabular}{c|c|c|c|c|c}
\hline & $\begin{array}{c}\text { Green logistics } \\
\text { attitude }\end{array}$ & $\begin{array}{c}\text { Green logistics } \\
\text { knowledge }\end{array}$ & $\begin{array}{c}\text { Green logistics } \\
\text { behavior }\end{array}$ & $\begin{array}{c}\text { Green logistics } \\
\text { desire }\end{array}$ & $\begin{array}{c}\text { Green Logistics } \\
\text { awareness }\end{array}$ \\
\hline Mean & 2.93 & 4.29 & 2.48 & 2.74 & 3.1 \\
\hline $\begin{array}{c}\text { Standard } \\
\text { error }\end{array}$ & 0.8669 & 0.9247 & 0.8966 & 0.8061 & 0.4923 \\
\hline
\end{tabular}

Source: Author's research. 
According to Table 3, the mean score of green logistics awareness is 3.1. This means that current enterprise green logistics awareness is at a relatively common level. According to the scores of the various dimensions of green logistics, green logistics knowledge is shown to have the highest influence on green logistics awareness. Of the four factors, green logistics behavior is the least influential, indicating that in general, enterprise has bad condition in green logistics behavior and verifies and supports the former's opinion.

\section{Conclusion and Inspiration}

This study attempted to empirically evaluate green logistics awareness in China and its constituent dimensions. The conclusions drawn from this study are as the following.

First, green logistics awareness is comprised of various dimensions. According to the results of the factor analysis, green logistics awareness can be divided into four dimensions: green logistics attitude, green logistics knowledge, green logistics behavior, and green logistics desire. Among the four dimensions of green logistics environment awareness, green logistics attitude has the largest influence.

Second, with the exception of those with higher scores related to green logistics knowledge, green logistics awareness was low. As a result, it appears that environmental awareness is, at best, superficial.

Third, educational background demonstrated a clear influence on green logistics awareness. This influence is especially pronounced for employees who have received a college or higher education relative to those who did not. Currently, green logistics awareness among logistics workers is at a very low level, wherein only positive attitudes toward green logistics are present. Therefore, translating green logistics attitudes into behavior is of the utmost importance for promoting green logistics awareness. The government should (a) improve public opinion by increasing logistics environmental-protection publicity, (b) use rational environmental policy and provide economic incentives for adoption of positive green logistics attitudes and behaviors, and (c) make relevant legal specifications to transfer employees' green logistics attitudes into tangible behavior. 


\section{References}

Arcury T A, Scollay S J, Timothy P, "sex individual differences in environmental concern and know ledge : the case of acid rain[J]", <Sex Roles>, 1987, (16), 463-472.

Bolton, J (2003). Distribution and Logistics in Today's China. China Business Review, 30(5), 8-17. Retrieved from http://search.ebscohost.com/

Carter C, Jennings M, "Logistics social responsibility: an integrative framework[J]" 『Journal of Business Logistics』, 2002, 23(1), 80-145.

China's Retail Logistics Management Problems and Countermeasures. (n.d.). Enterprise Research Papers. Retrieved June 20, 2011, from http://eng.hi138.com/146219

Dunlap, Riley E, "Measuring endorsement of the new ecological paradigm : a revised scale[J]", 『Journal of social Issues』, 2000, 56(3), 425-442.

Dunlap, Riley E, Van Liere, et al. "The new environmental paradigm : a proposed measuring instrument and preliminary results[J]", 『Journal of Environmental education』, 1978, (9), 10-19

Ester P, Meer F D, "Determinants of individual environmental behavior : an outline of a behavioral model and some research finding $[\mathrm{J}]$ ", "The Netherlands' Journal of Sociology』, 1982, 18(1), 57-94

Green logistics development in China Problems and Solutions - China's economy Papers. (n.d.). Papers Download Center: Provides papers for all industries. Retrieved June 20, 2011, from http://eng.hi138.com/

Jun jie, H (2007). Logistics development in China: a provider perspective. Transportation Journal, 46, (2), 55-65. Retrieved from http://search.ebscohost.com/1

Kim, Hyung-geun, "A research for the competiveness of China's automobile industry cluster -Focusing on the cluster in China's northeastern region-", Journal of International logistics and trade, Vol. 9, No.1, 2011, 10-18. 
Marshall, Alan (2004, July). Huge challenges for logistics and transport in China. CILT World, (10), 13-13.1. Retrieved from http://search.ebscohost.com/

Murphy, Paul R, Richard F P, et al. "Role and relevance of logistics to corporate environmentalism : an empirical assessment[J]", "International Journal of Physical Distribution and Logistics management』, 1995, 25(2), 5-19

Several problems in the logistics sector in China (2011, June 20.). Jobs in Logistics. Retrieved June 20, 2011, from http://www.jobsinlogistics.org

Shen J, Saijo T, "The relations between socio demographic characteristics and individual environmental concern : evidence from Shanghai data[J]", 『Journal of Environmental psychology』, 2008, (28), 42-50.

Shister, N (2008) . What Does the China Logistics Scene Look Like on the Ground? World Trade, 21(3), 20-20. Retrieved from http://search.ebscohost.com/

Tradesse T, "Environmental concern and its implication to household waste separation and disposal : Evidence from Melcelle, Ethiopia[J]", "Resources, Conservation and Recycling』, 2009, (53), 783-797.

Wu H J, Dunn S C, "Environmentally responsible logistics systems[J]", International Journal of Physical Distribution and Logistics Management』, 1995, 25(2), 20-38. 